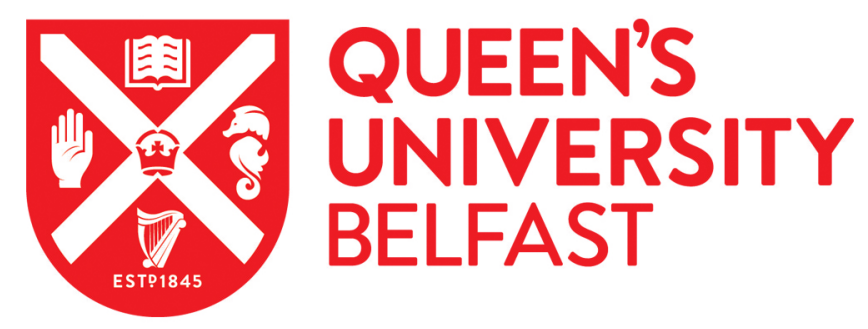

\title{
Are the differences in adulthood ill-health across the North-South divide and between Scotland and England also evident in early childhood health indicators?
}

Cruise, S. M., \& O'Reilly, D. (2015). Are the differences in adulthood ill-health across the North-South divide and between Scotland and England also evident in early childhood health indicators? Social Science and Medicine, 130, 277-283. https://doi.org/10.1016/j.socscimed.2015.02.021

Published in:

Social Science and Medicine

Queen's University Belfast - Research Portal:

Link to publication record in Queen's University Belfast Research Portal

\author{
Publisher rights \\ Copyright $\odot 2015$ Published by Elsevier Ltd.
}

This is the author's version of a work that was accepted for publication in Social Science and Medicine. Changes resulting from the publishing process, such as peer review, editing, corrections, structural formatting, and other quality control mechanisms may not be reflected in this document. Changes may have been made to this work since it was submitted for publication. A definitive version was subsequently published in Social Science and Medicine, VOL 130 (April 2015) doi:10.1016/j.socscimed.2015.02.021

General rights

Copyright for the publications made accessible via the Queen's University Belfast Research Portal is retained by the author(s) and / or other copyright owners and it is a condition of accessing these publications that users recognise and abide by the legal requirements associated with these rights.

\section{Take down policy}

The Research Portal is Queen's institutional repository that provides access to Queen's research output. Every effort has been made to ensure that content in the Research Portal does not infringe any person's rights, or applicable UK laws. If you discover content in the Research Portal that you believe breaches copyright or violates any law, please contact openaccess@qub.ac.uk. 
Are the differences in adulthood ill-health across the North-South divide and between Scotland and England also evident in early childhood health indicators?

Sharon Mary Cruise ${ }^{1,2} \&$ Dermot O’Reilly ${ }^{1,2}$

${ }^{1}$ Centre for Public Health, Institute of Clinical Sciences Block B, Queen's University Belfast, Royal Victoria Hospital, Northern Ireland, United Kingdom.

${ }^{2}$ UKCRC Centre of Excellence for Public Health (NI), Centre for Public Health, Queen's University Belfast, Royal Victoria Hospital, Northern Ireland, United Kingdom.

\section{Corresponding Author:}

Sharon Mary Cruise, Centre for Public Health, Institute of Clinical Sciences Block B, Queen's University Belfast, Royal Victoria Hospital, Grosvenor Road, Belfast, BT12 6BJ, Northern Ireland, United Kingdom.

Phone: 0044 (0)28 90632720; Fax: 0044 (0)28 90235900; email: s.cruise@qub.ac.uk

\section{Acknowledgements:}

This study forms part of a larger project that is funded by the Health Research Board, Ireland. We thank the families participating in the Millennium Cohort Study (MCS), and the UK Data Archive who administer the MCS data. Finally, we thank the reviewers for their helpful comments. 


\section{ABSTRACT}

Regional differences in adult morbidity and mortality within England (i.e., north-south divide or gradient) and between England and Scotland (i.e., Scottish effect) are only partly explained by adult levels of socioeconomic status or risk factors. This suggests variation in early life, and is supported by the fetal origins and life-course literature which posits that birth outcomes and subsequent, cumulative exposures influence adult health. However, no studies have examined the north-south gradient or Scottish effect in health in the earliest years of life. The aims of the study were: i) to examine health indicators in English and Scottish children at birth and age three to establish whether regional differences exist; and ii) to establish whether observed changes in child health at age three were attributable to birth and/or early life environmental exposures. Respondents included 10,639 biological Caucasian mothers of singleton children recruited to the Millennium Cohort Study (MCS) in the year 2000.

Outcome variables were: gestational age and birth weight, and height, body mass index (BMI), and externalising behavioural problems at age three. Region/country was categorised as: South (reference), Midlands, North (England), and Scotland. Respondents provided information on child, maternal, household, and socioeconomic characteristics. Results indicated no significant regional variations for gestational age or birth weight. At age three there was a north-south gradient for externalising behaviour and a north-south divide in BMI which attenuated on adjustment. However, a north-south divide in height was not fully explained by adjustment. There was also evidence of a 'Midlands effect', with increased likelihood of shorter stature and behaviour problems. Results showed a Scottish effect for height and BMI in the unadjusted models, and height in the adjusted model, but a decreased likelihood of behaviour problems. Findings indicated no regional differences in health at birth, but some regional variation at age three supports the cumulative life-course model. 
Keywords: England, Scotland, north-south divide, Scottish effect, health inequalities, child health, life-course 


\section{INTRODUCTION}

The north-south divide in adult health within England is a well documented, persistent phenomena of worse health outcomes for those living in the north of England compared to those in the south, and has also been observed as a gradient of increasingly worse health from the south, through the midlands, to the north of England (Doran, Drever, \& Whitehead, 2004; Hacking, Muller, \& Buchan, 2011; Leyland, 2004; Wells \& Gordon, 2008). These differences are somewhat, but not entirely explained by variations in socioeconomic status (SES) or other factors such as lifestyle or social composition within regions (Doran et al., 2004; Hacking et al., 2011).

Similarly, Scotland exhibits higher mortality rates than England that go back to at least 1925 , and have been increasing since the middle of the $20^{\text {th }}$ century, especially for men (Campbell, Ballas, Dorling, \& Mitchell, 2013). Even compared to similarly deprived areas in other parts of Britain, Scotland has a history of higher mortality rates (Hanlon et al., 2005). These findings have led to the term 'the Scottish effect', and as with the north-south divide in England, the higher mortality risk in Scotland is only partially explained by differences in deprivation levels (Hanlon et al., 2005) or variations in lifestyle or risk factor levels (Mitchell, Fowkes, Blane, \& Bartley, 2005). More recently, Shelton (2009) has also identified evidence of a Scottish effect in the prevalence of risk factors for cardiovascular disease in a comparison of Scottish and English regions. However, the relationship between area and risk factor was complex, and varied in strength and direction according to gender and risk factor.

Research investigating the north-south divide and the Scottish effect has typically focused on adult mortality and morbidity. However, it seems plausible to examine patterns of regional differences in early life health indicators as these may be the precursors to regional differences in later life health outcomes. We know from the fetal origins and life-course literature (Barker, 1992; Ben-Shlomo \& Kuh, 2002; Power \& Hertzman, 1997) that birth and 
early life outcomes are associated with a range of adverse health outcomes in the adult years. For example, associations that are independent of the effects of birth weight have been established between preterm birth and cardiovascular disease, hypertension, and glycaemic dysregulation (Dalziel, Parag, Rodgers, \& Harding, 2007; Doyle, 2008). Similarly, substantive literature has documented relationships between low birth weight and cardiovascular disease (Eriksson, Forsén, Tuomilehto, Osmond, \& Barker, 2001; Kaijser et al., 2008; Rich-Edwards et al., 2005), hypertension (Eriksson, Forsén, Tuomilehto, Osmond, \& Barker, 2000; Ramadhani et al., 2006), and metabolic syndrome (Eriksson et al., 2000; Newsome et al., 2003; Ramadhani et al., 2006) in adulthood. Evidence suggests an inverse association between height and cardiovascular disease (Paajanen, Oksala, Kuukasjärvi, \& Karhunen, 2010; The Emerging Risk Factors Collaboration, 2012), height and cardiorespiratory disease (Davey Smith et al., 2000; McCarron, Okasha, McEwen, \& Davey Smith, 2002), and an association between high body mass index (BMI) in childhood and the development of type 2 diabetes, hypertension, and coronary heart disease in adulthood (Park, Falconer, Viner, \& Kinra, 2012; Reilly \& Kelly, 2011). Finally, evidence indicates that behavioural problems in childhood are associated with increased risk in a number of healthrelated areas in adulthood including: obesity, substance misuse, risky sexual behaviour (e.g., multiple partners; teen pregnancy/parenthood), injury, hospitalisation due to road traffic accidents, chronic widespread pain, long-term illness, psychological ill health, mortality (by midlife), and criminal behaviour (von Stumm et al., 2011; Fergusson, Horwood, \& Ridder, 2005; Timmermans, van Lier, \& Koot 2008; Jokela, Power, \& Kivimäki, 2009; Redelmeier, Chan, \& Lu, 2010; Pang, Jones, Power, \& Macfarlane, 2010; Clark, Rodgers, Caldwell, Power, \& Stansfeld, 2007; Jokela, Ferrie, \& Kivimäki, 2009; Murray, Irving, Farrington, Colman, \& Bloxsom, 2010). Finally, evidence indicates that behavioural problems in childhood are associated with increased risks in a number of health-related areas in adulthood 
including: obesity (von Stumm, Deary, Kivimäki, et al., 2011), substance misuse (von Stumm, Deary, Kivimäki, et al. 2011; Fergusson, Horwood, Ridder, 2005), risky sexual behaviour (e.g., multiple partners; teen pregnancy/parenthood) (Fergusson, Horwood, Ridder, 2005), injury (Jokela, Power, Kivimäki, 2009), hospitalisation due to road traffic accidents (Redelmeier, Chan, Lu, 2010), chronic widespread pain (Pang, Jones, Power, et al., 2010), long-term illness (von Stumm, Deary, Kivimäki, et al., 2011), psychological ill health (Fergusson, Horwood, Ridder, 2005; Clark, Rodgers, Caldwell, et al., 2007), mortality (by midlife) (Jokela, Ferrie, Kivimäki, 2009), and criminal behaviour (Fergusson, Horwood, Ridder, 2005; Murray, Irving, Farrington, et al., 2010).

Therefore, there is a rationale for examining early life health indicators in order to understand patterns of regional differences that may be present at birth, or that may emerge during the first few years of life. Moreover, if regional differences in health are present at birth and in the early years, important policy implications are imminent. For example, if the origins of chronic disease are largely determined in the fetal and early life periods, public health interventions should target this important life-stage. Moreover, whilst the impact of birth characteristics (Barker, 1992; Gluckman, Hanson, Spencer, \& Bateson, 2005) and the accumulation of subsequent and varied early life environmental exposures on adult health is well-established (Power \& Hertzman, 1997), there is little research focused directly towards the impact of such variables on health outcomes in the shorter term (i.e., during the first few years of life).

To date, there are no studies that have explicitly examined the north-south divide (or gradient) or the Scottish effect in health in the earliest years of life. Therefore, the aims of this study were twofold. First, we aimed to examine health indicators in English and Scottish children at birth and at three years of age in order to establish whether regional differences exist - it was hypothesised that if the antecedents of regional variations in adult health are 
determined at an early stage then similar variations should be present, and will be evident as markedly worse health at birth or during the infancy/early childhood period for those living in the north of England (compared to the south of England), and for those living in Scotland (compared to the south of England). The five health indicators examined were: gestational age and weight at birth, and height, BMI, and externalising behaviour problems at three years of age. The second aim of the present study was to establish whether observed changes in health at age three were attributable to birth characteristics and/or early life environmental factors.

\section{METHODS}

\section{Sample Population}

Respondents were the biological mothers of singleton children enrolled in the Millennium Cohort Study (MCS), a nationally representative birth cohort study of children born across the UK in the year 2000 (see cohort profile by Connelly \& Platt, 2014). The present study is concerned with data collected in waves 1 (baseline) and 2 (second stage of data collection) of the MCS in England and Scotland when the cohort child was aged nine months and three years respectively. It should be noted that attrition rates at wave 2 for families with lower (or no) education was higher in Scotland than in England, thus affecting the representativeness of the Scottish sample at wave 2. Children of non-biological mothers (1.8\% of total sample), and from non-singleton pregnancies ( $1.4 \%$ of total sample) were excluded because of their potential to confound results. There were also a small numbers of cases that had incomplete data for maternal age, maternal ethnicity, mother's employment, number of siblings, tenure, and car availability $(\mathrm{N}=20)$ which were also excluded from analysis. These exclusions left a sample size of 13365 . Frequency analysis showed the proportion of non-white ethnicities in Scotland was small (2.2\%) compared to the other 
regions (see Table 1), therefore, children of non-white/non-Caucasian mothers were excluded from further analysis. The final sample sizes for analysis with valid data on each of the five outcome variables were as follows: gestational age, $\mathrm{N}=10575$; birth weight, $\mathrm{N}=10512$; height, $\mathrm{N}=8233$; BMI, $\mathrm{N}=8143$; and externalising behaviour $\mathrm{N}=8576$. Ethical approvals for the MCS waves 1 and 2 were granted by the South West Multicentre Research Ethics Committee (MREC) and London MREC respectively.

\section{Measurements}

\section{Outcome variables}

All outcome variables were coded as binary. Gestational age comprised a preterm $\left(25^{+0}-37^{+0}\right.$ weeks $)$ versus term group $\left(37^{+1}-43^{+0}\right.$ weeks $)$. Birth weight comprised a low birth weight (LBW) $(0.500-2.500 \mathrm{kgs})$ versus normal group ( $>2.500 \mathrm{kgs})$. Height comprised a 'short for age and gender' (at age three) versus normal group. The Center for Disease Control (CDC) standardised (z-scores) norms for height (by age and gender) were used as a reference (Kuczmarski et al., 2002), with a height of $\geq 1$ standard deviation below the mean being the cut-off. Child BMI was available as a 4-category derived variable; for the purpose of the present analysis this variable was further aggregated to comprise an 'overweight/obese' versus an 'underweight/normal' group (at age three). Externalising behaviour comprised two groups; 'behaviour problems' and 'no behaviour problems' (at age three) which was derived by summing scores on the hyperactivity and conduct disorders scales of the parent-completed Strengths and Difficulties Questionnaire (SDQ; Goodman, Ford, Simmons, Gatward, \& Meltzer, 2000; Goodman, Renfrew, \& Mullick, 2000; Goodman, Lamping, \& Ploubidis, 2010). Children were identified as having problem behaviour (i.e., 'caseness') if they scored $\geq 90^{\text {th }}$ percentile (based on the England and Scotland MCS sample percentiles) on the externalising scale. 


\section{Primary covariate}

Region was the primary covariate and included England and Scotland. England was disaggregated into the following three regions reflecting the north-south divide: the South (London and the south, east, south-east, and south-west of England; reference); the Midlands (east and west Midlands); and the North (north-east and north-west of England, Yorkshire, and Humberside).

\section{Confounding variables}

Child characteristics were birth weight (except where birth weight and gestational age were the outcome variables), gestational age (except where gestational age was the outcome variable), gender, parity (except where BMI and behaviour were the outcome variables), and breastfeeding status (except where gestational age and birth weight were the outcome variables). Birth weight comprised five categories: $1.500-2.500 \mathrm{kgs}, 2.501-3.000 \mathrm{kgs}, 3.001-$ $3.500 \mathrm{kgs}$ (reference), 3.501-4.000 kgs, and 4.001-4.600 kgs. Gestational age comprised three categories: $25^{+0}-37^{+0}$ weeks (preterm), $37^{+1}-41^{+0}$ weeks (normal term; reference), and $41^{+1}$ $43^{+0}$ weeks (late term). Gender comprised male and female (reference). Parity comprised two categories: multiparous and nulliparous (reference). Breastfeeding comprised two categories: never and ever (reference).

Maternal characteristics included mother's current age, her BMI and employment status. Mother's age comprised three categories: 16-29, 30-39 (reference), and 40+. Mother's pre-pregnancy BMI was calculated using height and pre-pregnancy weight measurements that were available in the dataset. Respondents were allocated to the standard WHO BMI groupings (i.e., underweight $\left[<18 \mathrm{~kg} / \mathrm{m}^{2}\right.$ ], normal weight [reference; $18-24.99 \mathrm{~kg} / \mathrm{m}^{2}$ ], overweight [25-29.99 kg/m ${ }^{2}$, obese [ $\left.\geq 30 \mathrm{~kg} / \mathrm{m}^{2}\right]$ ) based on their individual BMI levels. Mother's employment status included not working and working (reference). No distinction was made between full- or part-time employment. For analyses with gestational age and 
birthweight as the outcome variables, mother's pre-pregnancy employment status was used; for the analyses with height, BMI, and externalising behaviour as the outcome variable, mother's current employment status was used (i.e., when the child was aged three years).

Household characteristics included having a partner in the household (no partner; partner [reference]) and whether the child had any siblings (except where gestational age, birth weight, and height were the outcome variables) (one sibling; two or more siblings; no siblings [reference]). The presence of siblings in the household was included as a possible confounder for BMI and behaviour problems at age three in preference to parity as interaction between siblings could influence both outcomes.

Socioeconomic characteristics included household social class, mother's educational level, housing tenure, and car availability. In households where two caregivers were resident, household social class was derived from whichever of the two caregivers had the highest NSSEC classification (5-category; highest [ref] through to lowest). In single-parent households, the household social class was derived from the single parent. For analyses where height, BMI, and behaviour were the outcome variables, social class at age three years was the preferred social class variable. However, if social class data was missing at age three years, but available at age nine months, the nine-month social class data was used in order to counteract the missing data for social class at age three years. Mother's highest educational level comprised secondary education and higher education (reference). Housing tenure comprised tenant and owner (reference). The tenant category included respondents who indicated living rent-free, living with parents, or squatting. Car availability comprised no availability and availability (reference).

Statistical analysis

A series of binary logistic regressions were conducted with birth weight, gestational age, child height, child BMI, and externalising behaviour as the outcome variable in each 
instance. Regressions were conducted with and without adjustment for child characteristics, maternal, household, and socioeconomic characteristics. A 'missing' category was included for all covariates/confounding variables where there were larger amounts of missing data.

\section{RESULTS}

Frequency analyses of the five health outcome variables indicated that $7.6 \%$ of the total sample was born $\leq 37$ weeks gestation, $5.5 \%$ weighed $\leq 2.500 \mathrm{kgs}$ at birth, and $12.4 \%$ had a height $\geq 1$ SD below the CDC standardised recommended height for age and gender at age three. Further, $23.3 \%$ were in the overweight or obese weight category at age three, and $10.1 \%$ scored at or above the $90^{\text {th }}$ percentile on the SDQ externalising behaviour scale at age three.

Table 1 shows child, maternal, household, and socioeconomic characteristics cross tabulated by region for the baseline sample at wave 1 . There was no evidence of a northsouth gradient or Scottish effect for either gestational age or birth weight. There was the anticipated north-south gradient for proportions of younger mothers $(52.8 \%, 47.0 \%, 40.5 \%)$, mothers with lower educational levels $(61.2 \%, 57.6 \%, 56.0 \%)$, unemployed mothers $(36.9 \%$, $33.8 \%, 29.7 \%)$, mothers in the lowest social class $(49.5 \%, 43.9 \%, 36.5 \%)$, and mothers with no access to a vehicle $(19.3 \%, 14.3 \%, 12.3 \%)$. There were also North and South differences for mothers without a resident partner (17.3\% vs $11.5 \%)$, mothers who were tenants $(40.1 \%$ vs $35.5 \%)$, and mothers who did not breastfeed the cohort child (53.3\% vs $31.5 \%)$. There was evidence of a Scottish effect for those who were not breastfeeding (49.0\% vs $31.5 \%$ in South), and younger motherhood (44.5\% vs $40.5 \%$ in South). Patterns of BMI were comparable across the regions, as were the number of siblings in the household. The highest proportion of non-white ethnicities was in the South (14.2\%); proportions in the Midlands and North were comparable (10\%). However, Scotland had notably lower proportions of non- 
white ethnicities (2.2\%), thus supporting the decision to exclude all non-white ethnicities from further analyses.

\section{$<$ INSERT TABLE $1>$}

Table 2 summarises the results of a series of unadjusted and adjusted binary logistic regressions examining the effects of region on each health indicator (see Supplementary tables S1-S5 showing detailed results of the unadjusted, sequential, and fully adjusted models for each indicator). Results indicated that children in the North were $13 \%$ (CIs $0.95-1.35$ ) more likely to be born preterm than children in the South, an effect that attenuated when adjusted for maternal characteristics (OR1.07; CIs 0.89-1.28). A similar pattern was observed for birth weight, with effects for the North in the unadjusted model (OR 1.16; CIs 0.95-1.43) that attenuated when adjusted for maternal characteristics (OR 1.03; CIs 0.80-1.33).

\section{$<$ INSERT TABLE $2>$}

Although all regions had higher proportions of short stature children compared to the South, the region with the largest proportion was the Midlands (13.9\% vs $11.0 \%$ in the South). This was reflected in an OR of 1.40 (CIs 1.16-1.69) that remained largely unattenuated in the adjusted model (OR 1.39; CIs 1.14-1.68), suggesting an effect very similar to a north-south divide or Scottish effect. Although there was no north-south gradient for height, children in the North were $22 \%$ (CIs 1.03-1.44) more likely than those in the South to be of short stature. This effect attenuated somewhat on adjustment for child characteristics (OR 1.15; CIs 0.97-1.37), in particular, birth weight and parity.

All regions had higher proportions of children with high BMI compared to the South, with Scotland showing the highest (25.0\% vs $21.6 \%$ in the South). Although children in the North were $14 \%$ (CIs 1.00-1.30) more likely than those in the South to have high BMI, these effects attenuated on adjustment. Children in the Midlands were more likely than those in the South to have high BMI (OR 1.17; CIs 1.01-1.36), and this effect remained largely unaffected 
by adjustment (OR 1.14; CIs 0.98-1.33). Similarly, Scottish children were more likely than those in the South to have high BMI (OR 1.19; CIs 1.04-1.37), an effect that was only marginally affected by adjustment (OR 1.12; CIs 0.97-1.29).

Externalising behaviour was the only health indicator that showed a clear north-south gradient, with children in the Midlands and the North being 33\% (CIs 1.09-1.62) and 50\% (CIs 1.27-1.77) more likely (respectively) than children in the South to have behaviour problems. These effects attenuated on adjustment, leaving no gradient; however, children in the Midlands were still 13\% (CIs 0.92-1.39) more likely than those in the South to exhibit behaviour problems. Contrary to there being a Scottish effect, the adjusted model indicated that children in this region were less likely (OR 0.77; CIs 0.62-0.95) than those in the South to have behaviour problems.

\section{DISCUSSION}

The hypothesis that there would be a north-south gradient within the regions of England and evidence of a Scottish effect between Scotland and England was not supported for either gestational age or birth weight. The hypothesized north-south gradient was partially supported at age three for height, BMI, and behaviour. However, there also appeared to be evidence of a 'Midlands effect' in height, and to a lesser extent in BMI and behaviour which was not hypothesized. The hypothesis that there would be a Scottish effect at age three was supported for height in both the unadjusted and adjusted models, and for BMI in the unadjusted model (though the CIs only just straddled 1 in the adjusted model). However, any effect that was evident for behaviour problems in Scottish children was in the opposite direction to that predicted: the adjusted model showed that Scottish children were $23 \%$ less likely than children in the South to have behaviour problems. Therefore, the findings of the present study do little to suggest that the established geographic variations in adult morbidity 
and mortality patterns within England and between England and Scotland are mirrored by similar patterns in health at birth. However, there was evidence of geographic variations in health by the age of three. Although these variations do not all follow a distinct north-south gradient or Scottish effect, they provide evidence for the cumulative model of life-course epidemiology proposed by Power and Hertzman (1997).

The literature suggests some possible explanations for these findings. For example, recent studies suggest the presence of a 'Scottish effect' in the north of England, meaning this region holds higher morbidity and/or mortality rates, comparable to those seen in Scotland, which cannot be explained entirely by socioeconomic disadvantage (Whynes, 2009). Of particular interest is a study that examined mortality rates from age $0-85+$ within fifty four of the most persistently disadvantaged constituencies across the UK (Tunstall, Mitchell, Gibbs, Platt, \& Dorling, 2007). Results indicated that for the 0-4-year-old age group, there were higher rates of mortality in the Midlands than in the North. Moreover, the mortality rates for Scotland for the 0-4-year-olds were lower than for either the Midlands or the North. This is particularly relevant to the findings of the present study which found increased likelihood of short stature, high BMI, and behaviour problems in children in the Midlands (compared to the South) than either the North or Scotland.

Tunstall et al.'s (2007) study also illustrated that mortality rates varied across the lifespan. This may support the argument that a north-south divide/gradient and/or Scottish effect in health may only become evident at older ages, and is congruent with the 'accumulation of risk' and 'pathways' models of life-course epidemiology which argue that it is not only the accumulation of exposure to risk factors across the life-course, but also the interactions between risk factors, situated with the context of the individual's sociodemographic and environmental characteristics, that ultimately determine health outcomes (Kuh, Ben-Shlomo, Lynch, Hallqvist, \& Power, 2003; Power \& Hertzman, 1997). 
There was very little variation in our data to suggest gradients or regional effects for either gestational age or birth weight. However, there was some evidence of the effects of birth weight, coupled with breastfeeding and parity in attenuating the ORs for height in the North. There was also evidence for the effects of breastfeeding in attenuating the ORs for BMI and externalising behaviour problems in the Midlands and the north of England at age three. These findings highlight the influence of early life factors on short-term future health outcomes, and provide some support for the second hypothesis, and the pathways model (Power \& Hertzman, 1997) which observed that changes in health outcomes at age three can be attributed (in part) to birth outcomes and early life exposures. However, on the basis of the study design we cannot definitely conclude that the kinds of regional differences that we currently see at age three are going to continue into adulthood, or that they are predictors of future/adult health problems. In addition, it is possible that the cohort of children growing up now differs significantly in early life factors from the generation that is currently demonstrating differing levels of chronic disease in later adulthood.

The strengths of the present study are the large and predominantly nationally representative sample that allowed for the adjustment of a number of possible confounding variables. Moreover, to our knowledge there have been no previous studies that have explicitly examined the north-south divide/gradient and Scottish effect in infant and early childhood health. Therefore, the present findings provide a valuable contribution to both the infant/child health and life-course epidemiology literatures. A possible limitation is the lack of representativeness of the Scottish sample at age three; it could be argued that the lack of (or counterintuitive) Scottish effects in the present study can be attributed to this. However, this is not a valid argument as it is hypothesised that the Scottish effect is evident across all socioeconomic groupings. Moreover, all models were adjusted for a range of indicators of socioeconomic position. 


\section{CONCLUSION}

It is evident from the findings of the present study that there are differences in child health indicators within England, and between Scotland and England, some of which are explained by SES and some of which are not. However, none of these differences are apparent at birth, but rather are emerging over time, suggesting that they are the result of the accumulation and interaction of multiple factors. It is also evident in the present study that the established geographic variations in adult morbidity are not mirrored in child health outcomes, but that alternative types of regional variation exist in the early years. This represents an important contribution to the fetal origins/life-course literature which has tended to focus on the impact of fetal/birth outcomes on adult morbidity and mortality rather than on emerging morbidity at an earlier stage of the life-course. Whether these findings are a true reflection of regional differences in early life indicators, simply a cohort effect, or whether they are indicative of changes in regional health disparities is a topic for future studies. Ongoing research is currently examining whether patterns of regional differences observed in the present study at age three continue into middle and late childhood, while further assessing the impact of early life factors on health outcomes in later childhood. 


\section{REFERENCES}

Barker, D.J.P. (1992). Fetal and infant origins of adult disease. BMJ Press: London.

Ben-Shlomo, Y., \& Kuh, D. (2002). A life course approach to chronic disease epidemiology: conceptual models, empirical challenges and interdisciplinary perspectives. International Journal of Epidemiology, 31, 285-293. http://dx.doi.org/10.1093/ije/31.2.285

Campbell, M., Ballas, D., Dorling, D., \& Mitchell, R. (2013). Mortality inequalities: Scotland versus England and Wales. Health and Place, 23, 179-186.

http://dx.doi.org/10.1016/j.healthplace.2013.06.004

Clark, C., Rodgers, B., Caldwell, T., Power, C., \& Stansfeld, S. (2007). Childhood and adulthood psychological ill health as predictors of midlife affective and anxiety disorders: the 1958 British Birth Cohort. Archives of General Psychiatry, 64, 668-678.

http://dx.doi:10.1001/archpsyc.64.6.668

Connelly, R., \& Platt, L. (2014). Cohort profile: UK Millennium Cohort Study (MCS). International Journal of Epidemiology, 43, 1719-1725.http://dx.doi.org/10.1093/ije/dyu001

Dalziel, S.R., Parag, V., Rodgers, A., \& Harding, J.E. (2007). Cardiovascular risk factors at age 30 following pre-term birth. International Journal of Epidemiology 36, 907-

915.http://dx.doi.org/10.1093/ije/dym067

Davey Smith, G., Hart, C., Upton, M., Hole, D., Gillis, C., Watt, G., et al. (2000). Height and risk of death among men and women: aetiological implications of associations with cardiorespiratory disease and cancer mortality. Journal of Epidemiology and Community Health, 54, 97-103. http://dx.doi.org/10.1136/jech.54.2.97

Doran, T., Drever, F., \& Whitehead, M. (2004). Is there a north-south divide in social class inequalities in health in Great Britain? Cross sectional study using data from the 2001 census. BMJ, 328, 1043-1045. http://dx.doi.org/10.1136/bmj.328.7447.1043

Doyle, L.W. (2008). Cardiopulmonary outcomes of extreme prematurity. Seminars in Perinatology, 32, 28-34. http://dx.doi.org/10.1053/j.semperi.2007.12.005

Eriksson, J.G., Forsén, T., Tuomilehto, J., Osmond, C., \& Barker, D. (2000). Fetal and childhood growth and hypertension in adult life. Hypertension, 36, 790-794.

http://dx.doi.org/10.1161/01.HYP.36.5.790

Eriksson, J.G., Forsén, T., Tuomilehto, J., Osmond, C., \& Barker, D.J.P. (2001). Early growth and coronary heart disease in later life: longitudinal study. BMJ, 322, 949-953. http://dx.doi.org/10.1136/bmj.322.7292.949

Fergusson, D.M., Horwood, L.J., \& Ridder, E.M. (2005). Show me the child at seven: the consequences of conduct problems in childhood for psychosocial functioning in adulthood. Journal of Child Psychology and Psychiatry, 46, 837-849. http://dx.doi.org/10.1111/j.14697610.2004.00387.x 
Gluckman, P.D., Hanson, M.A., Spencer, H.G., \& Bateson, P. (2005). Environmental influences during development and their later consequences for health and disease: implications for the interpretation of empirical studies. Proceedings of the Royal Society B, 272, 671-677. http://dx.doi.org/10.1098/rspb.2004.3001

Goodman, A., Lamping, D., \& Ploubidis, G. (2010). When to use broader internalising and externalising subscales instead of the hypothesised five subscales on the Strengths and Difficulties Questionnaire (SDQ): data from British parents, teachers and children. Journal of Abnormal Child Psychology, 38, 1179-1191. http://dx.doi.org/10.1007/s10802-010-9434-x

Goodman, R., Ford, T., Simmons, H., Gatward, R., \& Meltzer, H. (2000). Using the Strengths and Difficulties Questionnaire (SDQ) to screen for child psychiatric disorders in a community sample. British Journal of Psychiatry, 177, 534-539.

http://dx.doi.org/10.1192/bjp.177.6.534

Goodman, R., Renfrew, D., \& Mullick, M. (2000). Predicting type of psychiatric disorder from Strengths and Difficulties Questionnaire (SDQ) scores in child mental health clinics in London and Dhaka. European Child and Adolescent Psychiatry, 9, 129-134. http://dx.doi.org/10.1007/s007870050008

Gray, L. (2007). Comparisons of health-related behaviours and health measures between Glasgow and the rest of Scotland. Glasgow Centre for Population Health.

Hacking, J.M., Muller, S., \& Buchan, I.E. (2011). Trends in mortality from 1965 to 2008 across the English north-south divide: comparative observational study. BMJ, 342, d508. http://dx.doi.org/10.1136/bmj.d508

Hanlon, P., Lawder, R.S., Buchanan, D., Redpath, A., Walsh, D., et al. (2005). Why is mortality higher in Scotland than in England and Wales? Decreasing influence of socioeconomic deprivation between 1981 and 2001 supports the existence of a 'Scottish Effect'. Journal of Public Health, 27, 199-204. http://dx.doi.org/10.1093/pubmed/fdi002

Jokela, M., Ferrie, J., \& Kivimäki, M. (2009). Childhood problem behaviors and death by midlife: the British National Child Development Study. Journal of the American Academy of Child and Adolescent Psychiatry, 48, 19-24.

http://dx.doi.org/10.1097/CHI.0b013e31818b1c76

Jokela, M., Power, C., \& Kivimäki, M. (2009). Childhood problem behaviors and injury risk over the life course. Journal of Child Psychology and Psychiatry, 50, 1541-1549. http://dx.doi.org/10.1111/j.1469-7610.2009.02122.x

Kaijser, M., Bonamy, A.K.E., Akre, O., Cnattingius, S., Granath, F., et al. (2008). Perinatal risk factors for ischemic heart disease: disentangling the roles of birth weight and preterm birth. Circulation, 117, 405-410. http://dx.doi.org/10.1161/CIRCULATIONAHA.107.710715

Kuczmarski, R.J., Ogden, C.L., Guo, S.S., Grummer-Strawn, L.M., Flegal, K.M., et al., (2002). 2000 CDC growth charts for the United States: methods and development. Vital Health Statistics, 11(246). National Center for Health Statistics. 
Kuh, D., Ben-Shlomo, Y., Lynch, J., Hallqvist, J., \& Power, C. (2003). Life course epidemiology. Journal of Epidemiology and Community Health, 57, 778-783.

http://dx.doi.org/10.1136/jech.57.10.778

Leyland, A.H. (2004). Increasing inequalities in premature mortality in Great Britain. Journal of Epidemiology and Community Health, 58, 296-302.

http://dx.doi.org/10.1136/jech.2003.007278

McCarron, P., Okasha, M., McEwen, J., \& Davey Smith, G. (2002). Height in young adulthood and risk of death from cardiorespiratory disease: a prospective study of male former students of Glasgow University, Scotland. American Journal of Epidemiology, 155, 683-687. http://dx.doi.org/10.1093/aje/155.8.683

Mitchell, R., Fowkes, G., Blane, D., \& Bartley, M. (2005). High rates of ischaemic heart disease in Scotland are not explained by conventional risk factors. Journal of Epidemiology and Community Health, 59, 565-567. http://dx.doi.org/10.1136/jech.2004.029850

Murray, J., Irving, B., Farrington, D.P., Colman, I., \& Bloxsom, C.A.J. (2010). Very early predictors of conduct problems and crime: results from a national cohort study. Journal of Child Psychology and Psychiatry, 51, 1198-1207. http://dx.doi.org/10.1111/j.14697610.2010.02287.x

Newsome, C.A., Shiell, A.W., Fall, C.H.D., Phillips, D.I.W., Shier, R., et al. (2003). Is birthweight related to later glucose and insulin metabolism - a systematic review. Diabetic Medicine, 20, 339-348. http://dx.doi.org/10.1046/j.1464-5491.2003.00871.x

Paajanen, T.A., Oksala, N.K.J., Kuukasjärvi, P., \& Karhunen, P.J. (2010). Short stature is associated with coronary heart disease: a systematic review of the literature and a metaanalysis. European Heart Journal, 31, 1802-1809. http://dx.doi.org/10.1093/eurheartj/ehq155

Pang, D., Jones, G.T., Power, C., \& Macfarlane, G.J. (2010). Influence of childhood behaviour on the reporting of chronic widespread pain in adulthood: results from the 1958 British Birth Cohort Study. Rheumatology, 49, 1882-1888.

http://dx.doi.org/10.1093/rheumatology/keq052

Park, M.H., Falconer, C., Viner, R.M., \& Kinra, S. (2012). The impact of childhood obesity on morbidity and mortality in adulthood: a systematic review. Obesity Review, 13, 985-1000. http://dx.doi.org/10.1111/j.1467-789X.2012.01015.x

Power, C., \& Hertzman, C. (1997). Social and biological pathways linking early life and adult disease. British Medical Bulletin, 53, 210-221.

http://dx.doi.org/10.1093/oxfordjournals.bmb.a011601

Ramadhani, M.K., Grobbee, D.E., Bots, M.L., Cabezas, M.C., \& Vos, L.E., et al. (2006). Lower birth weight predicts metabolic syndrome in young adults: the Atherosclerosis Risk in Young Adults (ARYA)-study. Atherosclerosis, 184, 21-27.

http://dx.doi.org/10.1016/j.atherosclerosis.2005.03.022 
Redelmeier, D.A., Chan, W.K., \& Lu, H. (2010). Road trauma in teenage male youth with childhood disruptive behavior disorders: a population based analysis. PLoS Medicine, 7, e1000369. http://dx.doi.org/10.1371/journal.pmed.1000369

Reilly, J.J., \& Kelly, J. (2011). Long-term impact of overweight and obesity in childhood and adolescence on morbidity and premature mortality in adulthood: systematic review. International Journal of Obesity, 35, 891-898. http://dx.doi.org/10.1038/ijo.2010.222

Rich-Edwards, J.W., Kleinman, K., Michels, K.B., Stampfer, M.J., Manson, J.E., et al. (2005). Longitudinal study of birth weight and adult body mass index in predicting risk of coronary heart disease and stroke in women. BMJ, 330, 1115.

http://dx.doi.org/10.1136/bmj.38434.629630.E0

Shelton, N.J. (2009). Regional risk factors for health inequalities in Scotland and England and the "Scottish effect". Social Science and Medicine, 69, 761-767.

http://dx.doi.org/10.1016/j.socscimed.2009.06.044

The Emerging Risk Factors Collaboration (2012). Adult height and the risk of cause-specific death and vascular morbidity in 1 million people: individual participant meta-analysis. International Journal of Epidemiology, 41, 1419-1433. http://dx.doi.org/10.1093/ije/dys086

Timmermans, M., van Lier, P.A.C., \& Koot, H.M. (2008). Which forms of child/adolescent externalizing behaviors account for late adolescent risky sexual behavior and substance use? Journal of Child Psychology and Psychiatry, 49, 386-394. http://dx.doi.org/10.1111/j.14697610.2007.01842.x

Tunstall, H., Mitchell, R., Gibbs, J., Platt, S., \& Dorling, D. (2007). Is economic adversity always a killer? Disadvantaged areas with relatively low mortality rates. Journal of Epidemiology and Community Health, 61, 337-343.

http://dx.doi.org/10.1136/jech.2006.049890

von Stumm, S., Deary, I.J., Kivimäki, M., Jokela, M., Clark, H., et al. (2011). Childhood behavior problems and health at midlife: 35-year follow-up of a Scottish birth cohort. Journal of Child Psychology and Psychiatry, 52, 992-1001. http://dx.doi.org/10.1111/j.14697610.2011.02373.x

Walsh, D., Bendel, N., Jones, R., \& Hanlon, P. (2010). It's not 'just deprivation': why do equally deprived UK cities experience different health outcomes? Public Health, 124, $487-$ 495. http://dx.doi.org/10.1016/j.puhe.2010.02.006

Wells, C., \& Gordon, E. (2008). Geographical variations in premature mortality in England and Wales, 1981-2006. Health Statistics Quarterly, 38, 6-18.

Whynes, D.K. (2009). Deprivation and self-reported health: are there 'Scottish effects' in England and Wales? Journal of Public Health, 31, 147-153.

http://dx.doi.org/10.1093/pubmed/fdn089 
Table 1. Child, maternal, household, and socioeconomic characteristics of the sample at Wave 1 (unweighted n; weighted \%)

\begin{tabular}{|c|c|c|c|c|c|c|c|}
\hline & & & & South & Midlands & North & Scotland \\
\hline Total N & & & Total N (\%) & 4246 & 1572 & 2596 & 2225 \\
\hline \multirow{15}{*}{$\begin{array}{l}\text { Maternal } \\
\text { characteristics }\end{array}$} & \multirow[t]{3}{*}{ Age } & $16-29$ & $6572(51.5)$ & 2507 (40.5) & $1158(47.0)$ & $1840(52.8)$ & 1067 (44.5) \\
\hline & & $30-39$ & 6334 (44.9) & 3005 (55.5) & $927(49.8)$ & 1279 (44.5) & $1123(51.5)$ \\
\hline & & $40+$ & 459 (3.6) & $236(4.0)$ & $60(3.2)$ & $77(2.7)$ & $86(4.1)$ \\
\hline & \multirow[t]{2}{*}{ Ethnicity } & White & $10641(89.5)$ & $4246(85.8)$ & $1573(89.1)$ & 2597 (89.9) & $2225(97.8)$ \\
\hline & & Other & $2724(10.5)$ & $1502(14.2)$ & $572(10.9)$ & $599(10.1)$ & $51(2.2)$ \\
\hline & \multirow{5}{*}{$\begin{array}{l}\text { Pre- } \\
\text { pregnancy } \\
\text { BMI }\end{array}$} & Underweight & $770(5.0)$ & $325(5.0)$ & $111(4.0)$ & $213(5.9)$ & $121(4.9)$ \\
\hline & & Normal & $8117(63.1)$ & 3485 (63.2) & $1264(62.1)$ & $1899(62.0)$ & $1469(65.1)$ \\
\hline & & Overweight & 2453 (18.5) & 1030 (18.3) & $416(19.2)$ & 589 (18.3) & $418(18.4)$ \\
\hline & & Obese & $1105(8.2)$ & 477 (8.3) & $198(9.6)$ & $259(7.9)$ & $171(7.4)$ \\
\hline & & Missing & $920(5.2)$ & $431(5.2)$ & $156(5.2)$ & $236(5.9)$ & $97(4.3)$ \\
\hline & \multirow[t]{3}{*}{ Education } & Higher & $3271(28.4)$ & $1708(32.4)$ & $426(26.6)$ & $499(20.0)$ & $638(30.3)$ \\
\hline & & Secondary & 7538 (57.3) & 3109 (56.0) & $1204(57.6)$ & $1944(61.2)$ & $1281(55.8)$ \\
\hline & & Missing & $2556(14.3)$ & $931(11.6)$ & $515(15.8)$ & $753(18.8)$ & $357(13.9)$ \\
\hline & \multirow[t]{2}{*}{ Employment } & Working & $8258(68.2)$ & 3694 (70.3) & $1187(66.2)$ & $1792(63.1)$ & $1585(71.0)$ \\
\hline & & Not working & 5107 (31.8) & $2054(29.7)$ & $958(33.8)$ & 1404 (36.9) & $691(29.0)$ \\
\hline \multirow{14}{*}{$\begin{array}{l}\text { Household } \\
\text { characteristics }\end{array}$} & \multirow[t]{2}{*}{ Partner } & Has partner & $11220(86.5)$ & 4924 (88.5) & $1831(87.5)$ & 2557 (82.7) & 1908 (85.5) \\
\hline & & No partner & 2145 (13.5) & $824(11.5)$ & $314(12.5)$ & 639 (17.3) & $368(14.5)$ \\
\hline & \multirow[t]{2}{*}{ Siblings } & None & $5653(43.1)$ & $2472(43.7)$ & $827(40.1)$ & $1323(42.2)$ & $1031(45.0)$ \\
\hline & & 1 or more & 7712 (56.9) & 3276 (56.3) & $1318(59.9)$ & $1873(57.8)$ & $1245(55.0)$ \\
\hline & \multirow{6}{*}{$\begin{array}{l}\text { Household } \\
\text { social class }\end{array}$} & Highest & $2572(22.8)$ & $1338(26.3)$ & $347(22.8)$ & 395 (15.7) & $492(23.0)$ \\
\hline & & 2 & $1587(13.1)$ & $741(14.1)$ & $210(11.0)$ & $327(11.6)$ & $309(14.0)$ \\
\hline & & 3 & $1078(8.7)$ & $550(10.3)$ & $156(8.1)$ & $212(7.2)$ & $160(7.5)$ \\
\hline & & 4 & $1268(9.8)$ & $536(9.5)$ & $194(9.6)$ & 295 (9.6) & $243(11.0)$ \\
\hline & & Lowest & $6010(41.5)$ & 2266 (36.5) & 1061 (43.9) & $1674(49.5)$ & 1009 (42.0) \\
\hline & & Missing & $850(4.1)$ & 317 (3.4) & $177(4.7)$ & $293(6.4)$ & $63(2.5)$ \\
\hline & \multirow[t]{2}{*}{ Tenure } & Owner & 7657 63.5) & 3300 (64.5) & $1225(65.9)$ & 1749 (59.9) & $1383(63.5)$ \\
\hline & & Tenant & $5708(36.5)$ & $2448(35.5)$ & $920(34.1)$ & $1447(40.1)$ & $893(36.5)$ \\
\hline & \multirow[t]{2}{*}{ Car } & Has car & $10810(85.4)$ & $4783(87.7)$ & $1700(85.7)$ & $2418(80.7)$ & 1909 (85.6) \\
\hline & & No car & $2555(14.6)$ & 965 (12.3) & $445(14.3)$ & 778 (19.3) & $367(14.4)$ \\
\hline \multirow{14}{*}{$\begin{array}{l}\text { Child } \\
\text { characteristics }\end{array}$} & \multirow{4}{*}{$\begin{array}{l}\text { Gestational } \\
\text { age }\end{array}$} & Preterm & $1043(7.6)$ & $454(7.8)$ & $146(6.3)$ & 274 (8.2) & $169(7.5)$ \\
\hline & & Normal & $9453(70.5)$ & 4078 (70.5) & 1568 (73.3) & $2234(70.2)$ & $1573(69.0)$ \\
\hline & & Postterm/late & $2732(21.1)$ & $1151(20.8)$ & $402(19.8)$ & $658(20.8)$ & 521 (22.9) \\
\hline & & Missing & $137(0.8)$ & $65(0.8)$ & $29(0.6)$ & $30(0.8)$ & $13(0.6)$ \\
\hline & \multirow[t]{6}{*}{ Birthweight } & $1.500-2.500$ & $816(5.3)$ & $357(5.2)$ & $149(5.5)$ & $206(5.9)$ & $104(4.4)$ \\
\hline & & $2.501-3.000$ & $2292(15.3)$ & $971(15.2)$ & $421(17.1)$ & $610(17.1)$ & $290(12.4)$ \\
\hline & & $3.001-3.500$ & 4817 (36.2) & 2101 (36.6) & 757 (36.2) & 1131 (35.5) & $828(36.0)$ \\
\hline & & $3.501-4.000$ & $3936(31.1)$ & $1626(29.7)$ & $598(30.3)$ & $940(31.3)$ & $772(34.5)$ \\
\hline & & $4.001-4.600$ & $1242(10.3)$ & $576(11.3)$ & $188(9.8)$ & 239 (8.2) & 239 (10.7) \\
\hline & & Missing & $262(1.9)$ & $117(2.0)$ & $32(1.1)$ & $70(2.1)$ & $43(2.0)$ \\
\hline & \multirow[t]{2}{*}{ Gender } & Female & 6493 (48.5) & $2783(48.5)$ & $1060(48.6)$ & $1564(49.3)$ & $1086(47.5)$ \\
\hline & & Male & $6872(51.5)$ & 2965 (51.5) & $1085(51.4)$ & $1632(50.7)$ & $1190(52.5)$ \\
\hline & \multirow[t]{2}{*}{ Breastfed } & Ever & 7605 (58.5) & 3925 (68.5) & $1164(56.0)$ & $1414(46.7)$ & $1102(51.0)$ \\
\hline & & Never & $5760(41.5)$ & $1823(31.5)$ & $981(44.0)$ & $1782(53.3)$ & $1174(49.0)$ \\
\hline
\end{tabular}

Ethnicity is included in frequency table for completeness; however, ethnicity was excluded from regression models owing to small proportions of ethnic minorities in Scotland 
Table 2. Summary of results of unadjusted and fully adjusted binary logistic regressions examining effects of region on gestational age and weight at birth, and height, BMI, and externalising behaviour problems at three years of age

\begin{tabular}{|c|c|c|c|c|c|c|c|c|c|}
\hline & & & \multirow{2}{*}{$\begin{array}{l}\text { South } \\
\text { Ref }\end{array}$} & \multicolumn{2}{|c|}{ Midlands } & \multicolumn{2}{|c|}{ North } & \multicolumn{2}{|c|}{ Scotland } \\
\hline & & & & OR & $95 \% \mathrm{Cls}$ & OR & $95 \% \mathrm{Cls}$ & OR & $95 \% \mathrm{Cls}$ \\
\hline \multirow[t]{6}{*}{ Birth outcomes } & Gestational age & $\mathrm{n} / \mathrm{N}(\mathrm{wtd} \%)$ & $321 / 4215(7.7)$ & \multicolumn{2}{|c|}{$103 / 1568(6.2)$} & \multicolumn{2}{|c|}{$220 / 2580(8.3)$} & \multicolumn{2}{|c|}{$168 / 2212(7.7)$} \\
\hline & (preterm) & Unadjusted & 1.00 & 0.85 & $0.68,1.07$ & 1.13 & $0.95,1.35$ & 1.00 & $0.82,1.21$ \\
\hline & & Adjusted $^{1}$ & 1.00 & 0.84 & $0.66,1.05$ & 1.07 & $0.89,1.28$ & 0.97 & $0.80,1.18$ \\
\hline & Birthweight & $\mathrm{n} / \mathrm{N}(\mathrm{wtd} \%)$ & $238 / 4203(5.4)$ & \multicolumn{2}{|c|}{$85 / 1557(5.0)$} & \multicolumn{2}{|c|}{$167 / 2556(6.4)$} & \multicolumn{2}{|c|}{$114 / 2196(5.1)$} \\
\hline & $(\leq 2.5 \mathrm{~kg})$ & Unadjusted & 1.00 & 0.96 & $0.75,1.24$ & 1.16 & $0.95,1.43$ & 0.91 & $0.73,1.15$ \\
\hline & & Adjusted $^{2}$ & 1.00 & 1.06 & $0.78,1.45$ & 1.03 & $0.80,1.33$ & 0.85 & $0.64,1.12$ \\
\hline \multirow[t]{9}{*}{ Age 3 outcomes } & Height & $\mathrm{n} / \mathrm{N}(\mathrm{wtd} \%)$ & $372 / 3346(11.0)$ & \multicolumn{2}{|c|}{ 192/1287 (13.9) } & \multicolumn{2}{|c|}{$263 / 1989(13.0)$} & \multicolumn{2}{|c|}{ 221/1611 (13.7) } \\
\hline & ( $\leq 1 \mathrm{SD}$ below mean) & Unadjusted & 1.00 & 1.40 & $1.16,1.69^{\star * *}$ & 1.22 & $1.03,1.44^{*}$ & 1.27 & $1.06,1.52^{* *}$ \\
\hline & & Adjusted $^{3}$ & 1.00 & 1.39 & $1.14,1.68^{* * *}$ & 1.15 & $0.97,1.37$ & 1.33 & $1.11,1.60^{\star *}$ \\
\hline & BMI & $\mathrm{n} / \mathrm{N}(\mathrm{wtd} \%)$ & $726 / 3311(21.6)$ & \multicolumn{2}{|c|}{$316 / 1278(24.6)$} & \multicolumn{2}{|c|}{ 476/1967 (24.0) } & \multicolumn{2}{|c|}{$398 / 1587(25.0)$} \\
\hline & (overweight/obese) & Unadjusted & 1.00 & 1.17 & $1.01,1.36^{*}$ & 1.14 & $1.00,1.30 \S$ & 1.19 & $1.04,1.37^{*}$ \\
\hline & & Adjusted $^{4}$ & 1.00 & 1.14 & $0.98,1.33$ & 1.08 & $0.94,1.23$ & 1.12 & $0.97,1.29$ \\
\hline & Externalising & $\mathrm{n} / \mathrm{N}(w t d \%)$ & $347 / 3487(9.4)$ & \multicolumn{2}{|c|}{ 171/1334 (11.4) } & \multicolumn{2}{|c|}{ 292/2053 (12.6) } & \multicolumn{2}{|c|}{$150 / 1702(8.0)$} \\
\hline & behaviour & Unadjusted & 1.00 & 1.33 & $1.09,1.62^{* *}$ & 1.50 & $1.27,1.77^{* * *}$ & 0.87 & $0.72,1.07$ \\
\hline & $\left(\geq 90^{\text {th }} \%\right.$ ile on SDQ $)$ & Adjusted $^{5}$ & 1.00 & 1.13 & $0.92,1.39$ & 1.08 & $0.90,1.29$ & 0.77 & $0.62,0.95^{*}$ \\
\hline
\end{tabular}

${ }^{1}$ Model adjusted for: child characteristics (gender, parity); maternal characteristics (age, pre-pregnancy BMI, educational level, pre-pregnancy employment status); household characteristics (partner in household); socioeconomic status (household social class, housing tenure, availability of a car)

${ }^{2}$ Model adjusted for: child characteristics (gestational age, gender, parity); maternal characteristics (age, pre-pregnancy BMI, educational level, pre-pregnancy employment status); household characteristics (partner in household); socioeconomic status (household social class, housing tenure, availability of a car)

${ }^{3}$ Model adjusted for: child characteristics (gestational age, birthweight, ever breastfed, parity); maternal characteristics (age, educational level, current employment status); household

characteristics (partner in household); socioeconomic status (household social class, housing tenure, availability of a car)

${ }^{4}$ Model adjusted for: child characteristics (gestational age, birthweight, ever breastfed, number of siblings); maternal characteristics (age, educational level, current employment status);

household characteristics (partner in household); socioeconomic status (household social class, housing tenure, availability of a car)

${ }^{5}$ Model adjusted for: child characteristics (gestational age, birthweight, gender, ever breastfed, number of siblings); maternal characteristics (age, educational level, current employment status);

household characteristics (partner in household); socioeconomic status (household social class, housing tenure, availability of a car)

$* p<0.05 ; * * p<0.01 ; * * * p \leq 0.001 ;{ }^{\S} p=.057$ 


\section{RESEARCH HIGHLIGHTS}

- Few studies have examined UK regional differences in early childhood health

- This study found no regional differences in birth weight and gestational age

- Some regional differences, including a 'Midlands effect' were evident by age three

- These findings support the cumulative effects of birth and infancy factors

- Results make important contribution to the life-course literature and health policy 
Table S1. Results of unadjusted, sequential, and fully adjusted models examining regional differences in gestational age

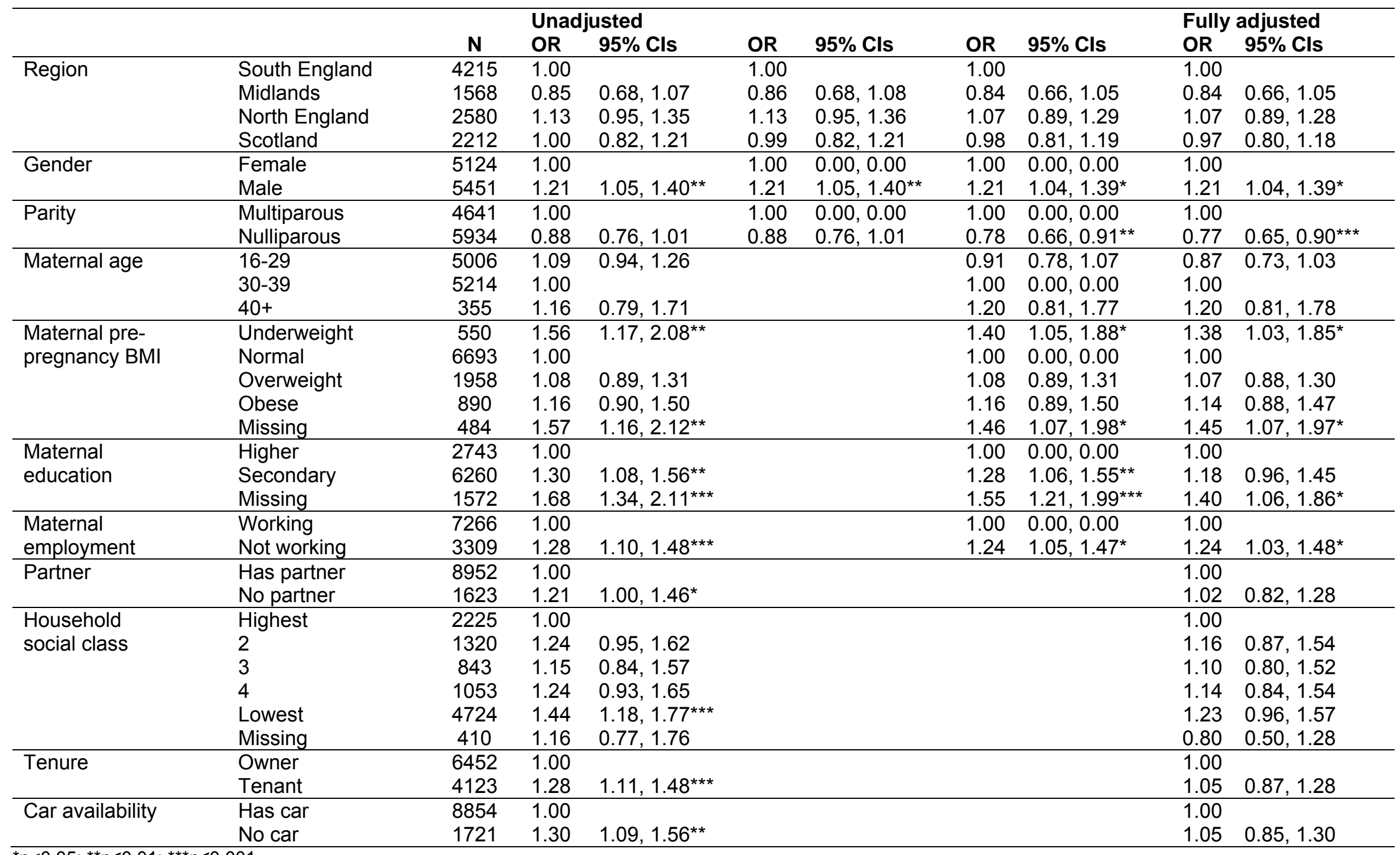

${ }^{*} p<0.05 ;{ }^{* *} p \leq 0.01 ;{ }^{* * *} p \leq 0.001$ 
Table S2. Results of unadjusted, sequential, and fully adjusted models examining regional differences in birthweight

\begin{tabular}{|c|c|c|c|c|c|c|c|c|c|c|}
\hline & & \multicolumn{3}{|c|}{ Unadjusted } & \multirow[b]{2}{*}{ OR } & \multirow[b]{2}{*}{ 95\% Cls } & \multirow[b]{2}{*}{ OR } & \multirow[b]{2}{*}{ 95\% Cls } & \multicolumn{2}{|c|}{ Fully adjusted } \\
\hline & & $\mathbf{N}$ & OR & $95 \%$ Cls & & & & & OR & 95\% Cls \\
\hline \multirow[t]{4}{*}{ Region } & South England & 4203 & 1.00 & & 1.00 & & 1.00 & & 1.00 & \\
\hline & Midlands & 1557 & 0.96 & $0.75,1.24$ & 1.08 & $0.80,1.46$ & 1.04 & $0.76,1.41$ & 1.06 & $0.78,1.45$ \\
\hline & North England & 2556 & 1.16 & $0.95,1.43$ & 1.14 & $0.89,1.45$ & 1.03 & $0.80,1.32$ & 1.03 & $0.80,1.33$ \\
\hline & Scotland & 2196 & 0.91 & $0.73,1.15$ & 0.90 & $0.69,1.18$ & 0.85 & $0.65,1.12$ & 0.85 & $0.64,1.12$ \\
\hline \multirow{4}{*}{$\begin{array}{l}\text { Gestational } \\
\text { age }\end{array}$} & Preterm & 810 & 34.47 & $28.25,42.07^{\star \star \star}$ & 36.05 & $29.43,44.17^{\star * *}$ & 37.70 & $30.58,46.47^{* * *}$ & 37.84 & $30.66,46.70^{* * *}$ \\
\hline & Normal & 7388 & 1.00 & & 1.00 & & 1.00 & & 1.00 & \\
\hline & Postterm/late & 2251 & 0.34 & $0.21,0.54^{* * *}$ & 0.33 & $0.21,0.52^{* * *}$ & 0.34 & $0.22,0.55^{* * *}$ & 0.34 & $0.21,0.54^{* * *}$ \\
\hline & Missing & 63 & 3.97 & $1.69,9.31^{* *}$ & 4.32 & $1.83,10.18^{* * *}$ & 3.63 & $1.51,8.73^{* *}$ & 3.50 & $1.46,8.44^{* *}$ \\
\hline \multirow[t]{2}{*}{ Gender } & Female & 5114 & 1.00 & & 1.00 & & 1.00 & & 1.00 & \\
\hline & Male & 5398 & 0.81 & $0.69,0.96^{*}$ & 0.63 & $0.52,0.77^{* * *}$ & 0.63 & $0.51,0.77^{* * *}$ & 0.63 & $0.51,0.77^{\star \star *}$ \\
\hline \multirow[t]{2}{*}{ Parity } & Multiparous & 4620 & 1.00 & & 1.00 & & 1.00 & & 1.00 & \\
\hline & Nulliparous & 5892 & 0.71 & $0.60,0.84^{* * *}$ & 0.66 & $0.54,0.80^{* * *}$ & 0.51 & $0.41,0.64^{* * *}$ & 0.49 & $0.39,0.62^{* * *}$ \\
\hline \multirow[t]{3}{*}{ Maternal age } & $16-29$ & 4987 & 1.19 & $1.01,1.41^{*}$ & & & 0.82 & $0.66,1.03$ & 0.72 & $0.57,0.92^{* *}$ \\
\hline & $30-39$ & 5170 & 1.00 & & & & 1.00 & & 1.00 & \\
\hline & $40+$ & 355 & 1.75 & $1.19,2.58^{* *}$ & & & 2.12 & $1.32,3.42^{\star *}$ & 2.18 & $1.35,3.53^{* * *}$ \\
\hline \multirow{5}{*}{$\begin{array}{l}\text { Maternal pre- } \\
\text { pregnancy BMI }\end{array}$} & Underweight & 551 & 2.28 & $1.73,3.02^{* * *}$ & & & 2.01 & $1.41,2.86^{* * *}$ & 1.89 & $1.32,2.70^{* * *}$ \\
\hline & Normal & 6667 & 1.00 & & & & 1.00 & & 1.00 & \\
\hline & Overweight & 1938 & 0.93 & $0.74,1.17$ & & & 0.86 & $0.66,1.13$ & 0.86 & $0.65,1.12$ \\
\hline & Obese & 878 & 0.88 & $0.64,1.22$ & & & 0.77 & $0.52,1.13$ & 0.74 & $0.50,1.08$ \\
\hline & Missing & 478 & 1.02 & $0.68,1.53$ & & & 0.63 & $0.39,1.02$ & 0.60 & $0.37,0.97^{*}$ \\
\hline \multirow{3}{*}{$\begin{array}{l}\text { Maternal } \\
\text { education }\end{array}$} & Higher & 2721 & 1.00 & & & & 1.00 & & 1.00 & \\
\hline & Secondary & 6211 & 1.51 & $1.21,1.90^{* * *}$ & & & 1.47 & $1.12,1.92^{* *}$ & 1.21 & $0.90,1.63$ \\
\hline & Missing & 1580 & 2.81 & $2.17,3.64^{\star * *}$ & & & 2.86 & $2.04,3.99^{* * *}$ & 2.19 & $1.50,3.19^{* \star *}$ \\
\hline \multirow{2}{*}{$\begin{array}{l}\text { Maternal } \\
\text { employment }\end{array}$} & Working & 7211 & 1.00 & & & & 1.00 & & 1.00 & \\
\hline & Not working & 3301 & 1.47 & $1.25,1.75^{\star * *}$ & & & 1.32 & $1.05,1.67^{*}$ & 1.23 & $0.96,1.58$ \\
\hline \multirow[t]{2}{*}{ Partner } & Has partner & 8888 & 1.00 & & & & & & 1.00 & \\
\hline & No partner & 1624 & 1.35 & $1.10,1.67^{* *}$ & & & & & 0.90 & $0.67,1.20$ \\
\hline Household & Highest & 2204 & 1.00 & & & & & & 1.00 & \\
\hline \multirow[t]{5}{*}{ social class } & 2 & 1306 & 1.28 & $0.91,1.80$ & & & & & 1.17 & $0.77,1.77$ \\
\hline & 3 & 834 & 1.55 & $1.07,2.25^{\star}$ & & & & & 1.51 & $0.97,2.36$ \\
\hline & 4 & 1042 & 1.71 & $1.22,2.40^{* *}$ & & & & & 1.59 & $1.04,2.42^{*}$ \\
\hline & Lowest & 4713 & 2.01 & $1.56,2.57^{* * *}$ & & & & & 1.49 & $1.05,2.11^{*}$ \\
\hline & Missing & 413 & 1.64 & $1.03,2.62^{*}$ & & & & & 0.87 & $0.47,1.63$ \\
\hline \multirow[t]{2}{*}{ Tenure } & Owner & 6384 & 1.00 & & & & & & 1.00 & \\
\hline & Tenant & 4128 & 1.75 & $1.49,2.07^{* * *}$ & & & & & 1.43 & $1.09,1.88^{* *}$ \\
\hline \multirow[t]{2}{*}{ Car availability } & Has car & 8787 & 1.00 & & & & & & 1.00 & \\
\hline & No car & 1725 & 1.62 & $1.33,1.97^{* * *}$ & & & & & 1.05 & $0.78,1.39$ \\
\hline
\end{tabular}

${ }^{*} p<0.05 ;{ }^{* *} p<0.01 ;{ }^{* * *} p \leq 0.001$ 
Table S3. Results of unadjusted, sequential, and fully adjusted models examining regional differences in height at age 3

\begin{tabular}{|c|c|c|c|c|c|c|c|c|c|c|c|c|}
\hline & & \multicolumn{3}{|c|}{ Unadjusted } & \multirow[b]{2}{*}{ OR } & \multirow[b]{2}{*}{$95 \%$ Cls } & \multirow[b]{2}{*}{ OR } & \multirow[b]{2}{*}{ 95\% Cls } & \multirow[b]{2}{*}{ OR } & \multirow[b]{2}{*}{$95 \%$ Cls } & \multicolumn{2}{|c|}{ Fully adjusted } \\
\hline & & $\mathbf{N}$ & OR & $95 \%$ Cls & & & & & & & OR & $95 \%$ Cls \\
\hline \multirow{4}{*}{ Region } & South England & 3346 & 1.00 & & 1.00 & & 1.00 & & 1.00 & & 1.00 & \\
\hline & Midlands & 1287 & 1.40 & $1.16,1.69^{* * *}$ & 1.39 & $1.15,1.68^{* * *}$ & 1.38 & $1.14,1.68^{* * *}$ & 1.38 & $1.14,1.68^{* * *}$ & 1.39 & $1.14,1.68^{* * *}$ \\
\hline & North England & 1989 & 1.22 & $1.03,1.44^{*}$ & 1.16 & $0.98,1.39$ & 1.15 & $0.97,1.38$ & 1.16 & $0.97,1.38$ & 1.15 & $0.97,1.37$ \\
\hline & Scotland & 1611 & 1.27 & $1.06,1.52^{* *}$ & 1.31 & $1.09,1.58^{* *}$ & 1.33 & $1.11,1.60^{* *}$ & 1.33 & $1.11,1.59^{* *}$ & 1.33 & $1.11,1.60^{* *}$ \\
\hline \multirow{4}{*}{$\begin{array}{l}\text { Gestational } \\
\text { age }\end{array}$} & Preterm & 613 & 1.95 & $1.58,2.40^{* * *}$ & 1.20 & $0.94,1.53$ & 1.20 & $0.94,1.54$ & 1.20 & $0.94,1.54$ & 1.20 & $0.94,1.54$ \\
\hline & Normal & 5800 & 1.00 & & 1.00 & & 1.00 & & 1.00 & & 1.00 & \\
\hline & Postterm/late & 1781 & 0.84 & $0.71,0.99^{*}$ & 1.07 & $0.90,1.28$ & 1.08 & $0.90,1.28$ & 1.08 & $0.90,1.29$ & 1.08 & $0.90,1.28$ \\
\hline & Missing & 39 & 3.16 & $1.59,6.26^{* * *}$ & 2.75 & $1.37,5.54^{* *}$ & 2.64 & $1.31,5.34^{* *}$ & 2.67 & $1.32,5.38^{* *}$ & 2.63 & $1.30,5.33^{* *}$ \\
\hline \multirow[t]{6}{*}{ Birthweight } & $1.500-2.500$ & 394 & 2.01 & $1.57,2.57^{* * *}$ & 1.85 & $1.38,2.47^{* * *}$ & 1.82 & $1.36,2.43^{* * *}$ & 1.82 & $1.36,2.44^{* * *}$ & 1.82 & $1.36,2.43^{* * *}$ \\
\hline & $2.501-3.000$ & 1190 & 1.28 & $1.07,1.54^{* *}$ & 1.27 & $1.06,1.53^{* *}$ & 1.26 & $1.05,1.52^{*}$ & 1.26 & $1.05,1.52^{*}$ & 1.26 & $1.05,1.52^{*}$ \\
\hline & $3.001-3.500$ & 2990 & 1.00 & & 1.00 & & 1.00 & & 1.00 & & 1.00 & \\
\hline & $3.501-4.000$ & 2666 & 0.53 & $0.44,0.62^{\star * *}$ & 0.51 & $0.43,0.61^{* * *}$ & 0.51 & $0.43,0.61^{* * *}$ & 0.51 & $0.43,0.61^{* * *}$ & 0.51 & $0.43,0.61^{* * *}$ \\
\hline & $4.001-4.600$ & 845 & 0.31 & $0.23,0.43^{* * *}$ & 0.30 & $0.22,0.42^{* * *}$ & 0.31 & $0.22,0.43^{* * *}$ & 0.31 & $0.22,0.43^{* * *}$ & 0.31 & $0.22,0.43^{* * *}$ \\
\hline & Missing & 148 & 1.48 & $0.98,2.24$ & 1.39 & $0.91,2.12$ & 1.38 & $0.90,2.11$ & 1.37 & $0.90,2.10$ & 1.38 & $0.90,2.11$ \\
\hline \multirow[t]{2}{*}{ Breastfed } & Ever & 4625 & 1.00 & & 1.00 & & 1.00 & $0.00,0.00$ & 1.00 & & 1.00 & \\
\hline & Never & 3608 & 1.18 & $1.04,1.35^{*}$ & 1.07 & $0.93,1.22$ & 1.00 & $0.87,1.16$ & 1.01 & $0.87,1.16$ & 1.00 & $0.87,1.16$ \\
\hline \multirow[t]{2}{*}{ Parity } & Multiparous & 3584 & 1.00 & & 1.00 & & 1.00 & $0.00,0.00$ & 1.00 & & 1.00 & \\
\hline & Nulliparous & 4649 & 1.24 & $1.09,1.42^{\star \star *}$ & 1.36 & $1.19,1.56^{\star * *}$ & 1.36 & $1.18,1.57^{* * *}$ & 1.35 & $1.17,1.56^{\star * *}$ & 1.36 & $1.17,1.57^{\text {***}}$ \\
\hline \multirow[t]{3}{*}{ Maternal age } & $16-29$ & 2517 & 1.14 & $0.99,1.31$ & & & 1.07 & $0.91,1.25$ & 1.08 & $0.92,1.27$ & 1.06 & $0.90,1.25$ \\
\hline & $30-39$ & 4946 & 1.00 & & & & 1.00 & $0.00,0.00$ & 1.00 & & 1.00 & \\
\hline & $40+$ & 770 & 0.97 & $0.76,1.22$ & & & 0.94 & $0.74,1.19$ & 0.94 & $0.74,1.19$ & 0.93 & $0.74,1.19$ \\
\hline \multirow{3}{*}{$\begin{array}{l}\text { Maternal } \\
\text { education }\end{array}$} & Higher & 2337 & 1.00 & & & & 1.00 & $0.00,0.00$ & 1.00 & & 1.00 & \\
\hline & Secondary & 4864 & 1.19 & $1.02,1.39^{*}$ & & & 1.05 & $0.89,1.24$ & 1.05 & $0.89,1.24$ & 1.06 & $0.89,1.27$ \\
\hline & Missing & 1032 & 1.60 & $1.30,1.98^{* * *}$ & & & 1.18 & $0.93,1.50$ & 1.20 & $0.94,1.53$ & 1.17 & $0.90,1.52$ \\
\hline \multirow{2}{*}{$\begin{array}{l}\text { Maternal } \\
\text { employment }\end{array}$} & Working & 4645 & 1.00 & & & & 1.00 & $0.00,0.00$ & 1.00 & & 1.00 & \\
\hline & Not working & 3588 & 1.26 & $1.11,1.43^{* * *}$ & & & 1.13 & $0.98,1.29$ & 1.13 & $0.98,1.30$ & 1.10 & $0.95,1.28$ \\
\hline \multirow[t]{2}{*}{ Partner } & Has partner & 6989 & 1.00 & & & & & & 1.00 & & 1.00 & \\
\hline & No partner & 1244 & 1.10 & $0.92,1.31$ & & & & & 0.92 & $0.76,1.11$ & 0.84 & $0.68,1.04$ \\
\hline Household & Highest & 2289 & 1.00 & & & & & & & & 1.00 & \\
\hline \multirow[t]{5}{*}{ social class } & 2 & 1024 & 1.01 & $0.80,1.27$ & & & & & & & 0.98 & $0.77,1.25$ \\
\hline & 3 & 939 & 1.09 & $0.87,1.38$ & & & & & & & 0.98 & $0.77,1.25$ \\
\hline & 4 & 846 & 1.10 & $0.86,1.40$ & & & & & & & 0.89 & $0.69,1.16$ \\
\hline & Lowest & 2992 & 1.23 & $1.04,1.45^{\star}$ & & & & & & & 0.97 & $0.79,1.18$ \\
\hline & Missing & 143 & 1.95 & $1.27,2.99^{* *}$ & & & & & & & 1.41 & $0.87,2.28$ \\
\hline \multirow[t]{2}{*}{ Tenure } & Owner & 5546 & 1.00 & & & & & & & & 1.00 & \\
\hline & Tenant & 2687 & 1.27 & $1.11,1.45^{\star * \star}$ & & & & & & & 1.05 & $0.87,1.27$ \\
\hline Car & Has car & 7118 & 1.00 & & & & & & & & 1.00 & \\
\hline availability & No car & 1115 & 1.35 & $1.14,1.61^{* * *}$ & & & & & & & 1.10 & $0.88,1.37$ \\
\hline
\end{tabular}


Table S4. Results of unadjusted, sequential, and fully adjusted models examining regional differences in BMI at age 3

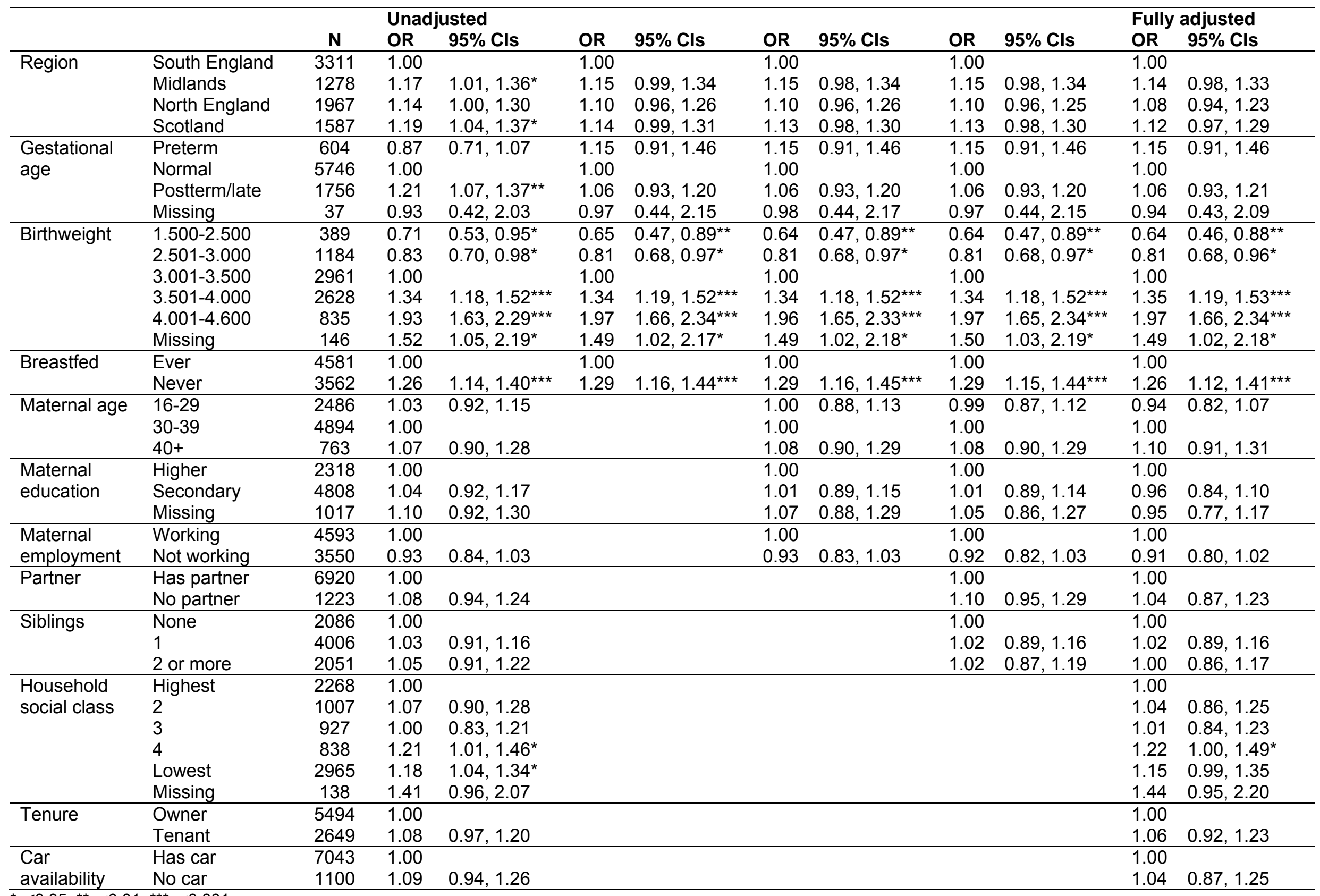

${ }^{*} \mathrm{p} \leq 0.05 ;{ }^{* \star} \mathrm{p}<0.01 ;{ }^{* \star *} \mathrm{p}<0.001$ 
Table S5. Results of unadjusted, sequential, and fully adjusted models examining regional differences in behaviour problems at age 3

\begin{tabular}{|c|c|c|c|c|c|c|c|c|c|c|c|c|}
\hline & & \multicolumn{3}{|c|}{ Unadjusted } & \multirow[b]{2}{*}{ OR } & \multirow[b]{2}{*}{$95 \%$ Cls } & \multirow[b]{2}{*}{ OR } & \multirow[b]{2}{*}{$95 \%$ Cls } & \multirow[b]{2}{*}{ OR } & \multirow[b]{2}{*}{$95 \%$ Cls } & \multicolumn{2}{|c|}{ Fully adjusted } \\
\hline & & $\mathbf{N}$ & OR & 95\% Cls & & & & & & & OR & $95 \%$ Cls \\
\hline \multirow[t]{4}{*}{ Region } & South England & 3487 & 1.00 & & 1.00 & & 1.00 & & 1.00 & & 1.00 & \\
\hline & Midlands & 1334 & 1.33 & $1.09,1.62^{* *}$ & 1.17 & $0.96,1.43$ & 1.14 & $0.93,1.40$ & 1.13 & $0.92,1.39$ & 1.13 & $0.92,1.39$ \\
\hline & North England & 2053 & 1.50 & $1.27,1.77^{* * *}$ & 1.22 & $1.03,1.45^{*}$ & 1.14 & $0.96,1.36$ & 1.13 & $0.95,1.35$ & 1.08 & $0.90,1.29$ \\
\hline & Scotland & 1702 & 0.87 & $0.72,1.07$ & 0.76 & $0.62,0.93^{* *}$ & 0.79 & $0.64,0.97^{*}$ & 0.80 & $0.65,0.99^{*}$ & 0.77 & $0.62,0.95^{*}$ \\
\hline \multirow{4}{*}{$\begin{array}{l}\text { Gestational } \\
\text { age }\end{array}$} & Preterm & 638 & 1.28 & $1.01,1.62^{*}$ & 0.99 & $0.75,1.32$ & 1.04 & $0.78,1.38$ & 1.02 & $0.76,1.36$ & 1.03 & $0.77,1.38$ \\
\hline & Normal & 6036 & 1.00 & & 1.00 & & 1.00 & & 1.00 & & 1.00 & \\
\hline & Postterm/late & 1863 & 0.93 & $0.78,1.10$ & 1.03 & $0.86,1.23$ & 1.05 & $0.88,1.26$ & 1.07 & $0.90,1.29$ & 1.07 & $0.89,1.28$ \\
\hline & Missing & 39 & 1.75 & $0.77,3.98$ & 1.59 & $0.69,3.68$ & 1.28 & $0.55,3.02$ & 1.18 & $0.50,2.77$ & 1.07 & $0.45,2.54$ \\
\hline \multirow[t]{6}{*}{ Birthweight } & $1.500-2.500$ & 413 & 1.46 & $1.10,1.95^{* *}$ & 1.44 & $1.03,2.00^{*}$ & 1.30 & $0.93,1.83$ & 1.34 & $0.95,1.88$ & 1.30 & $0.92,1.84$ \\
\hline & $2.501-3.000$ & 1233 & 1.29 & $1.06,1.56^{*}$ & 1.29 & $1.05,1.58^{*}$ & 1.21 & $0.99,1.49$ & 1.22 & $0.99,1.51$ & 1.19 & $0.97,1.47$ \\
\hline & $3.001-3.500$ & 3105 & 1.00 & & 1.00 & & 1.00 & & 1.00 & & 1.00 & \\
\hline & $3.501-4.000$ & 2776 & 0.87 & $0.73,1.02$ & 0.87 & $0.73,1.03$ & 0.91 & $0.77,1.08$ & 0.90 & $0.76,1.07$ & 0.91 & $0.77,1.09$ \\
\hline & $4.001-4.600$ & 893 & 0.70 & $0.53,0.91^{* *}$ & 0.70 & $0.53,0.92^{* *}$ & 0.78 & $0.59,1.03$ & 0.77 & $0.58,1.01$ & 0.79 & $0.60,1.05$ \\
\hline & Missing & 156 & 1.08 & $0.66,1.77$ & 1.07 & $0.64,1.77$ & 1.03 & $0.61,1.73$ & 1.02 & $0.61,1.73$ & 1.03 & $0.61,1.74$ \\
\hline \multirow[t]{2}{*}{ Gender } & Female & 4214 & 1.00 & & 1.00 & & 1.00 & & 1.00 & & 1.00 & \\
\hline & Male & 4362 & 1.55 & $1.35,1.77^{\star \star \star}$ & 1.64 & $1.43,1.89^{* * *}$ & 1.66 & $1.44,1.92^{* \star *}$ & 1.69 & $1.46,1.95^{\star * *}$ & 1.71 & $1.48,1.97^{* * *}$ \\
\hline \multirow[t]{2}{*}{ Breastfed } & Ever & 4825 & 1.00 & & 1.00 & & 1.00 & & 1.00 & & 1.00 & \\
\hline & Never & 3751 & 2.45 & $2.13,2.81^{\text {***}}$ & 2.38 & $2.06,2.74^{* * *}$ & 1.61 & $1.38,1.88^{* * *}$ & 1.57 & $1.34,1.83^{* * *}$ & 1.44 & $1.23,1.68^{* * *}$ \\
\hline \multirow[t]{3}{*}{ Maternal age } & $16-29$ & 2609 & 2.61 & $2.27,3.00^{* \star *}$ & & & 1.78 & $1.53,2.07^{* \star *}$ & 1.81 & $1.54,2.11^{* * *}$ & 1.49 & $1.26,1.76^{* * *}$ \\
\hline & $30-39$ & 5167 & 1.00 & & & & 1.00 & & 1.00 & & 1.00 & \\
\hline & $40+$ & 800 & 1.02 & $0.77,1.34$ & & & 1.05 & $0.79,1.39$ & 1.03 & $0.78,1.37$ & 1.08 & $0.81,1.43$ \\
\hline Maternal & Higher & 2445 & 1.00 & & & & 1.00 & & 1.00 & & 1.00 & \\
\hline \multirow[t]{2}{*}{ education } & Secondary & 5066 & 2.52 & $2.06,3.10^{* * *}$ & & & 1.69 & $1.36,2.10^{* * *}$ & 1.61 & $1.29,2.00^{* * *}$ & 1.36 & $1.08,1.72^{* *}$ \\
\hline & Missing & 1065 & 6.60 & $5.24,8.31^{* * *}$ & & & 3.29 & $2.55,4.25^{* * *}$ & 2.86 & $2.20,3.71^{* * *}$ & 2.05 & $1.54,2.72^{* * *}$ \\
\hline \multirow{2}{*}{$\begin{array}{l}\text { Maternal } \\
\text { employment }\end{array}$} & Working & 4848 & 1.00 & & & & 1.00 & & 1.00 & & 1.00 & \\
\hline & Not working & 3728 & 2.25 & $1.96,2.59^{* * *}$ & & & 1.56 & $1.35,1.81^{* * *}$ & 1.38 & $1.18,1.61^{* * *}$ & 1.23 & $1.05,1.45^{*}$ \\
\hline \multirow[t]{2}{*}{ Partner } & Has partner & 7278 & 1.00 & & & & & & 1.00 & & 1.00 & \\
\hline & No partner & 1298 & 2.67 & $2.29,3.11^{* * *}$ & & & & & 1.64 & $1.38,1.95^{\star * *}$ & 1.22 & $1.01,1.49^{*}$ \\
\hline \multirow[t]{3}{*}{ Siblings } & None & 2190 & 1.00 & & & & & & 1.00 & & 1.00 & \\
\hline & 1 & 4227 & 1.03 & $0.87,1.22$ & & & & & 1.30 & $1.08,1.56^{* *}$ & 1.31 & $1.09,1.58^{* *}$ \\
\hline & 2 or more & 2159 & 1.47 & $1.22,1.77^{\star \star \star}$ & & & & & 1.64 & $1.33,2.02^{\star * *}$ & 1.53 & $1.24,1.89^{* * *}$ \\
\hline Household & Highest & 2395 & 1.00 & & & & & & & & 1.00 & \\
\hline \multirow[t]{5}{*}{ social class } & 2 & 1068 & 1.30 & $0.97,1.74$ & & & & & & & 0.97 & $0.72,1.32$ \\
\hline & 3 & 1000 & 1.32 & $0.98,1.77$ & & & & & & & 1.00 & $0.74,1.36$ \\
\hline & 4 & 876 & 2.45 & $1.89,3.19^{* \star *}$ & & & & & & & 1.41 & $1.06,1.87^{*}$ \\
\hline & Lowest & 3095 & 3.35 & $2.75,4.08^{* * *}$ & & & & & & & 1.46 & $1.15,1.85^{\star *}$ \\
\hline & Missing & 142 & 8.28 & $5.61,12.24^{\star * *}$ & & & & & & & 1.71 & $1.10,2.67^{*}$ \\
\hline \multirow[t]{2}{*}{ Tenure } & Owner & 5784 & 1.00 & & & & & & & & 1.00 & \\
\hline & Tenant & 2792 & 3.38 & $2.94,3.87^{\star \star \star}$ & & & & & & & 1.44 & $1.19,1.74^{* * *}$ \\
\hline \multirow[t]{2}{*}{ Car availability } & Has car & 7405 & 1.00 & & & & & & & & 1.00 & \\
\hline & No car & 1171 & 3.54 & $3.04,4.13^{* \star *}$ & & & & & & & 1.40 & $1.15,1.70^{* * *}$ \\
\hline
\end{tabular}

